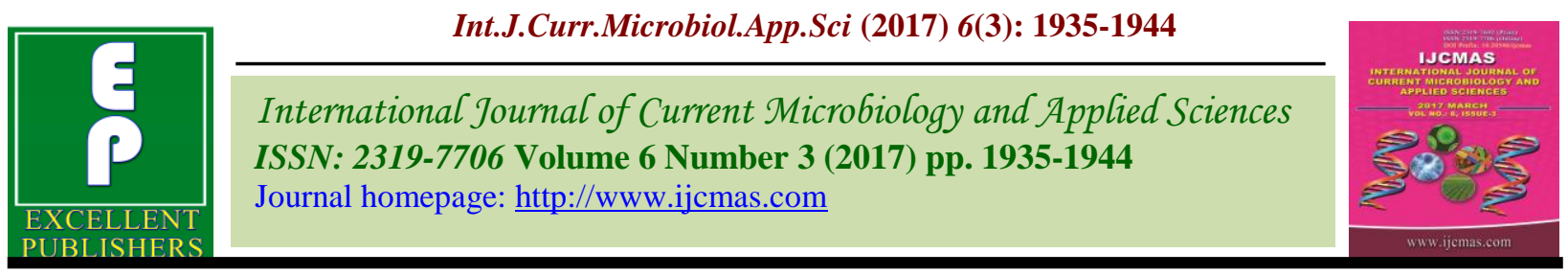

Original Research Article

https://doi.org/10.20546/ijcmas.2017.603.220

\title{
The Effect of Plant Growth Promoting Rhizobacteria (PGPR) on Biochemical Parameters of Coriander (Coriandrum sativum L.) Seedling
}

\author{
S.I. Warwate*, U.K. Kandoliya, N.V. Bhadja and B.A. Golakiya \\ Department of Biochemistry, College of Agriculture, Junagadh Agricultural University, \\ Junagadh- 362001 (GJ), India \\ *Corresponding author
}

\section{A B S T R A C T}

Keywords

PGPR, Azatobacter, PSB, Pseudomonas,

C. sativum,

Biochemical parameters, and days after germination (DAG).

Article Info

Accepted:

24 February 2017

Available Online:

10 March 2017

\begin{abstract}
Many, microorganisms playing an important role in plant growth are used in agriculture system, especially that group of microorganisms called plant growth promoting rhizobacteria (PGPR), which can increase the growth of plant directly and indirectly; acting as biofertilizers, phytostimulators and biocontrol agent. A pot experiment was conducted to evaluate the effect of inoculation of three plant growth promoting rhizobacteira (Azatobacer, PSB, Pseudomonas) either singly or in combination on biochemical parameters of coriander seedling. There were four different seedling stages 5 DAG, 10 DAG, 15 DAG, and 20 DAG. Seeds were inoculated with single and combined solution of $10^{8} \mathrm{CFU} / \mathrm{ml}$ of rhizobacteria. Seeds were not inoculated for the control variant. The combinations of given three PGPR had significantly increased biochemical parameters such as moisture content, total phenol, true protein, Indole-3-acetia acid (IAA), total soluble sugar, and reducing sugar in comparison to the individual and control treatment. Our study suggests that PGPR are environmental friendly and offer sustainable approach to increase production of crop and heath. So PGPR will restrict the use of chemical fertilizer in agriculture area.
\end{abstract}

\section{Introduction}

India is recognized as the "Home of spices" in all over the world. Whenever we think about spices it immediately strikes our mind about the hot, pungent, aromatic and spicy Indian dishes and cuisine, which are now becoming increasingly popular in the western countries. Coriander (Coriandrum sativum L.) is an important seed spice crop belonging to the family Apiaceae (previously classified under the family Umbelliferae) with a diploid chromosome number $2 \mathrm{n}=22$. Coriander displays broad adaptation as a crop around the world, growing well under many different types of soil and weather conditions
(Guenther 1952; Purseglove et al., 1981 and Simon, 1990). The green herb has high vitamin $\mathrm{C}$, vitamin $\mathrm{A}$, and vitamin $\mathrm{B}_{2}$ content (Girenko, 1982 and Prakash, 1990). Coriander is extensively used in western countries in flavouring of processed foods, including breads, cakes, sauces, meat products, soup and confectionery. Coriander seeds are used in tonic, carminative, diuretic, stomachic and as an aphrodisiac. Among the essential nutrients, Nitrogen $(\mathrm{N})$ and Phosphorus (P) are the primary nutrients in the soil which play crucial role in improving plant growth (Mohamed et al., 2011). Phosphorus is 
another most growth limiting nutrient for plant growth (Ezawa, 2002). Phosphorus is called "Key to life" because it is directly involved in most living process. Biological fertilizers like phosphate solubilizing microorganism (PSM) and plant growth promoting rhizobacteria (PGPR) are considered among the most important plant helper microorganism to supply nutrient at a favourable level and these fertilizers are absorbed on the basis of selection of beneficial soil microorganisms which has the highest efficiency to enhance plant growth by providing nutrients in a readily absorbable form. Surrounding plant roots there is an extremely important and active area for root activity and metabolism which is known as rhizosphere (Garcia et al., 2001). Bacteria inhabiting the rhizosphere and beneficial to plants are termed plant growth promoting rhizobacteria - PGPR (Kloepper et al., 1980). A rhizobacteria is qualified as PGPR when it is able to produce a positive effect on the plant upon inoculation (Barriuso et al., 2008). These bacteria significantly affect plant growth by: providing the host plant with fixed atmospheric nitrogen (Zhang et al., 1996), solubilization of soil phosphorus compounds (De Freitas et al., 1997), producing biologically active substances such as auxins and other plant hormones (Khalid et al., 2004), suppressing pathogens by producing antibiotics and siderophores (Khan and Almas, 2002). So the present investigation was planned to evaluate effect of PGPR on biochemical parameters of coriander seedling.

\section{Materials and Methods}

\section{Experimental site}

The present investigation was conducted in green house condition at Department of Biochemistry, College of Agriculture, Junagadh Agricultural University, Junagadh (Gujarat) during Rabi 2015-16.

\section{Experimental soil}

The soil was collected from Agronomy farm, Junagadh Agricultural University, Junagadh. These soil sterilized in autoclave dried properly and used for pot trial. There were 24 Pots, each with $40 \mathrm{~cm}$ deep and $45 \mathrm{~cm}$ wide, having capacity $40 \mathrm{~kg}$ soil/pot. Experimental soil was calcareous in texture and slightly alkaline in reaction having normal electrical conductivity.

\section{PGPR culture}

Three plant growth promoting rhizobacteria (Azatobacter, PSB, and Pseudomonas) were obtained from Microbial Cell, Department of Biotechnology, Junagadh Agricultural University, Junagadh.

\section{Seed materials}

The coriander seeds (cv. Gujarat Coriander-2) were obtained from Department of seed science and technology, Junagadh Agricultural University, Junagadh, India.

\section{Seed treatment}

Prior to treatments coriander seeds (Gujarat coriander-2) were sterilized with $70 \%$ ethanol and $0.1 \%$ mercuric chloride $(\mathrm{Hg})$ and washed with distilled water for 4 times. Pure culture of PGPR $\left(10^{8} \mathrm{CFU} / \mathrm{ml}\right)$ individually or in combination were treated with seeds. Seeds were not inoculated for control variant.

$\mathrm{T}_{1}$-Control

$\mathrm{T}_{2}$-Azatobacter

$\mathrm{T}_{3}$-PSB (Phosphate solubilizing bacteria)

$\mathrm{T}_{4}$-Pseudomonas

$\mathrm{T}_{5}$-Azatobacter $+\mathrm{PSB}$

$\mathrm{T}_{6}$-Azatobacter + Pseudomonas

$\mathrm{T}_{7}$-PSB + Pseudomonas

$\mathrm{T}_{8}$-Azatobacter + PSB + Pseudomonas 


\section{Pot trial}

Pot trials are conducted in green house of Biochemistry Department, College of Agriculture, J.A.U., Junagadh. After half an hour of seed treatment, they were sown in pots in three replications during December month. Sufficient water is supplied to pots till the last stage. The seedlings were analyzed in four stages viz., $S_{1}(5 \mathrm{DAG}), \mathrm{S}_{2}(10 \mathrm{DAG}), \mathrm{S}_{3}$ (15 DAG) and $\mathrm{S}_{4}(20 \mathrm{DAG})$.

\section{Biochemical parameters}

\section{Moisture}

Seedling moisture was measured by weighing randomly selected five seedlings and they placed in hot air oven for drying. Finally these samples was weighed and calculated the difference between fresh and oven dried seedlings, AOAC, (2005).

\section{Total phenol}

Suitable aliquot $(0.1 \mathrm{ml})$ of was taken from methanol extract prepared for total free amino acids analysis and evaporated to dryness in water bath. One $\mathrm{ml}$ of millipore water in each test tube and $0.5 \mathrm{ml}$ of Folin Ciocalteu's phenol reagent (1:1 with water) was added and kept for $3 \mathrm{~min}$. After this $2 \mathrm{ml}$ of $20 \%$ Sodium carbonate was added and mixed thoroughly.

The tubes were placed in boiling water for exactly one minute and cooled in ice water. The absorbance was read at $650 \mathrm{~nm}$ against a reagent blank (Bray and Thorpe, (1954). A standard graph was prepared using pyrocatachol ranging between 10concentrations. The amount of phenols present in the sample was calculated as -

Phenol $\left(\mathrm{mg} \cdot \mathrm{g}^{-1}\right)=$ Sample O.D. $\mathrm{x}$ Standard O.D. $x$ Dilution factor

\section{True protein}

The method of Folin-Lowry (Lowry et al., 1951) was used to estimate the protein content in the supernatant of enzyme extracts. Suitable aliquot $(0.2 \mathrm{ml})$ was taken and total 3 $\mathrm{ml}$ volume was made with distilled water. To that, $5.0 \mathrm{ml}$ of reagent $\mathrm{C}$ (Prepared by mixing $50 \mathrm{ml}$ of reagent A with $1 \mathrm{ml}$ of reagent B; A: $2 \%$ Sodium Carbonate in $0.1 \mathrm{~N}$ Sodium Hydroxide. B: $0.5 \%$ Copper sulphate in $1 \%$ Sodium Potassium tartrate) was added and mixed properly. After 10 minutes, $0.5 \mathrm{ml}$ of reagent D (D: Folin Ciocalteau reagent diluted with distilled water in 1:1 ratio) was added, thoroughly mixed and kept for 30 minutes at room temperature. The absorbance was measured at $660 \mathrm{~nm}$. The protein content was calculated by using Bovine serum albumin as standard.

Protein content $\left(\mathrm{mg} \cdot \mathrm{g}^{-1}\right)=$ Sample O.D. $\mathrm{x}$ Graph factor x Dilution factor

\section{Free amino acid}

Free amino acid content was estimated as described by Lee and Takahashi (1966). Suitable aliquots were taken and volume made up to $1 \mathrm{ml}$ by adding distilled water. To this, $5 \mathrm{ml}$ ninhydrin reagent $(1 \%$ ninhydrin in $500 \mathrm{mM}$ citrate buffer, pure glycerol, and 500 $\mathrm{mM}$ citrate buffer $\mathrm{pH} 5.5$ in the ratio of 5:12:2) was added, mixed thoroughly and then, tubes were kept in a boiling water bath for 12 minutes. After that, the tubes were transferred to an ice bath for immediate cooling.

The tubes were brought to room temperature and the absorbance was measured at $530 \mathrm{~nm}$. The free amino acid content was calculated from reference curve prepared using glycine $(10-100 \mu \mathrm{g})$ as standard and expressed as appropriate. 
Total free amino acids:

(mg. $\mathrm{ml}^{-1}$ or mg. $\left.\mathrm{g}^{-1}\right)=$ Sample O.D. $\mathrm{x}$ Standard O.D. x Dilution Factor

\section{Indole-3-acetic acid}

IAA content was determined as per the method given by Mazumdar et al., (2007). 0.5 gm seedling sample was extracted in $10 \mathrm{ml}$ of $80 \%$ methanol. The Tube was incubated overnight at room temperature. Aliquot of 0.2 , $0.4 \mathrm{ml}$ was taken in test tubes and volume made to $1 \mathrm{ml}$ with $\mathrm{D} / \mathrm{W}$. In that tube $2 \mathrm{ml}$ of $\mathrm{FeHclO}_{4}$ Solution was added and after 25 minutes reading was taken at $530 \mathrm{~nm}$.

\section{Total soluble sugar}

Seedlings (100 mg) were extracted with $5 \mathrm{ml}$ of $80 \%$ ethanol and centrifuged at $3000 \mathrm{rpm}$ for 10 minutes. Extraction was repeated 4 times with $80 \%$ ethanol and supernatants were collected into $25 \mathrm{ml}$ volumetric flasks. Final volume of the extract was made to 25 $\mathrm{ml}$ with $80 \%$ methanol. The extract $(0.3 \mathrm{ml})$ was pipetted into separate test tubes and the tubes were placed in a boiling water bath to evaporate the methanol. One $\mathrm{ml}$ of millipore water and $1 \mathrm{ml}$ of $5 \%$ phenol was added in each test tube. Then $5 \mathrm{ml}$ of sulphuric acid was added. The tubes were allowed to cool in ice-bath for 10-15 minutes. The intensity of colour was read at $490 \mathrm{~nm}$ on spectrophotometer. A standard curve was prepared using $10 \mathrm{mg}$ glucose per $100 \mathrm{ml}$ distilled water (Hedge and Hofreiter, (1962).

Total soluble sugar $\left(\mathrm{mg} \cdot \mathrm{g}^{-1}\right)=$ Sample O.D. $\times$ Standard O.D. $\times$ Dilution factor

\section{Reducing sugar}

The dinitrosalicylic acid (DNSA) method was used to estimate the glucose and galacturonic acid released by cellulase, polygalacturonase and $\beta-1,3$ glucanase enzymes (Miller, 1972). A known volume of aliquot was taken in test tube and final volume of $1.0 \mathrm{ml}$ adjusted with distilled water. To this $0.5 \mathrm{ml}$ DNSA reagent $(1 \mathrm{~g}$ DNSA $+200 \mathrm{mg}$ crystalline phenol +50 mg sodium sulphite in $100 \mathrm{ml}$ of $1 \%$ sodium hydroxide) was added and mixed properly. The content was heated in a boiling water bath for $5 \mathrm{~min}$. When the contents of the tubes were still warm, $1.0 \mathrm{ml}$ of $40 \%$ sodium potassium tartrate (Rochelle salt) solution was added. Cool it and final volume was made 5.0 $\mathrm{ml}$ with distilled water. After that the tubes were read at $540 \mathrm{~nm}$ using spectrophotometer. Reagent blank was also performed by addition of $1.0 \mathrm{ml}$ of distilled water in place of enzyme aliquot. A known concentration of standard $(0.5-2.5 \mu \mathrm{M})$ of glucose or galacturonic acid was carried out and was calibrated and expresses as appropriate.

Glucose/ galacturonic acid $=$ Sample O.D. $\mathrm{x}$ Standard O.D. x Dilution Factor $\left(\mu \mathrm{M} . \mathrm{mg}^{-1}\right.$ protein) $\mathrm{mg} \cdot \mathrm{ml}^{-1}$ or $\mathrm{mg} \cdot \mathrm{g}^{-1}$ protein

\section{Results and Discussion}

\section{Moisture content}

Changes of moisture content $(\%)$ due to various treatment of plant growth promoting rhizobacteria (PGPR) during different growth stages were presented in Table.1. The data showed significant differences for growth stages and treatments. For interaction effect it was non-significant. The value for the moisture content at different stages in a coriander seedling was varied from $89.27 \%$ to $90.67 \%$. The data at stage $\mathrm{S}_{1}(90.67 \%)$ was found significantly highest. Stage $\mathrm{S}_{4}$ $(89.27 \%)$ showed significantly lowest value indicates gains in dry matter with the growth of seedlings. So for as treatments and combinations, no clear cut trend was found for the moisture content. PGPR treatment increased moisture content in cabbage 
seedling compared to control one (Metin et al., 2014).

\section{Total phenol content, true protein, and free} amino acids

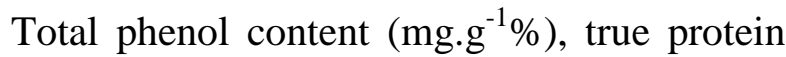
$(\%)$, and free amino acids (\%) data varied due to various treatment of plant growth promoting rhizobacteria (PGPR) during different growth stages were presented in Table.2. The data showed significant differences for growth stages, treatments, and interaction effect. The total phenol content in a coriander seedling was varied from 0.254 to $0.295 \mathrm{mg} . \mathrm{g}-1 \%$. The value for total phenol content was found for stage $\mathrm{S}_{4}(0.295 \mathrm{mg} . \mathrm{g}$ ${ }^{1} \%$ ) was significantly highest. Also reported that the plants growth promoting rhizobacteria (PGPR) induced the synthesis of specific phenolic acids, salicylic acid (SA) with varied amounts at different growth stages (Singh et al., 2003; Kandoliya and Vakharia, 2013). $\mathrm{T}_{8}$
(Azatobacter + PSB + Pseudomonas) (0.299 $\mathrm{mg} . \mathrm{g}^{-1} \%$ ) found significantly higher phenol content. In case of combination highest value was found for $\mathrm{S}_{4} \mathrm{~T}_{8}\left(0.324 \mathrm{mg} \cdot \mathrm{g}^{-1} \%\right)$. Alireza Pazoki (2015) reported that the, PGPR (Azospirillium, Azotobacter and Pseudomonas) diminished flavonoids (22\%) and increased phenols (17.9\%). Marcela et al., (2014) also reported that the combination of PGPR increased the total phenol content.

The value for true protein varies from 3.74 to $4.41 \%$. Highest true protein content in a coriander seedling was recorded for stage $\mathrm{S}_{4}$ $(4.41 \%)$. Stage $S_{1}$ recorded significantly lowest value for the true protein content. This indicates gain in protein content with the advancement of the growth stages. Irrespective of stages treatment $\mathrm{T}_{8}(5.03 \%)$ found significantly higher. Aishwath et al., (2012) observed that at 60 DAS the protein content was enhanced with individual and combine use of inoculants in coriander straw.

Table.1 Effect of Plant growth promoting rhizobacteria (PGPR) on moisture content of Coriander (C. sativum L.) seedling

\begin{tabular}{|c|c|c|c|c|c|}
\hline \multirow[b]{2}{*}{ Treatments } & \multicolumn{4}{|c|}{ Stages } & \multirow[b]{2}{*}{ Mean T } \\
\hline & $\begin{array}{c}S_{1} \\
(5 \text { DAG) }\end{array}$ & $\begin{array}{c}S_{2} \\
(10 \mathrm{DAG})\end{array}$ & $\begin{array}{c}S_{3} \\
(15 \text { DAG })\end{array}$ & $\begin{array}{c}\mathrm{S}_{4} \\
(20 \mathrm{DAG})\end{array}$ & \\
\hline $\mathbf{T}_{1}$ & 90.13 & 89.48 & 89.25 & 88.92 & 89.44 \\
\hline $\mathbf{T}_{2}$ & 90.49 & 89.71 & 89.54 & 89.11 & 89.71 \\
\hline $\mathbf{T}_{3}$ & 90.58 & 89.85 & 89.70 & 89.23 & 89.84 \\
\hline $\mathbf{T}_{4}$ & 90.28 & 89.59 & 89.41 & 89.01 & 89.57 \\
\hline $\mathbf{T}_{5}$ & 91.01 & 90.31 & 90.02 & 89.55 & 90.22 \\
\hline $\mathbf{T}_{6}$ & 90.75 & 89.98 & 89.80 & 89.34 & 89.97 \\
\hline $\mathbf{T}_{7}$ & 90.92 & 90.13 & 89.87 & 89.43 & 90.08 \\
\hline $\mathbf{T}_{8}$ & 91.17 & 90.49 & 90.15 & 89.58 & 90.35 \\
\hline Mean (S) & 90.67 & 89.94 & 89.72 & 89.27 & \\
\hline & $\mathbf{S}$ & $\mathbf{T}$ & $\mathbf{S} \times \mathbf{T}$ & & \\
\hline S.Em. \pm & 0.06 & 0.07 & 0.16 & & \\
\hline C.D. at5\% & 0.16 & 0.20 & N.S. & & \\
\hline C.V. \% & 0.38 & & & & \\
\hline
\end{tabular}

The values are mean of three replications

Where, $\mathrm{T}_{1^{-}}(\mathrm{Control}), \mathrm{T}_{2^{-}}$(Azatobacter), $\mathrm{T}_{3^{-}}(\mathrm{PSB}), \mathrm{T}_{4^{-}}$(Pseudomonas), $\mathrm{T}_{5^{-}}$(Azatobacter $\left.+\mathrm{PSB}\right), \mathrm{T}_{6^{-}}($Azatobacter + Pseudomonas), $\mathrm{T}_{7^{-}}$(PSB + Pseudomonas), $\mathrm{T}_{8^{-}}$(Azatobacter + PSB + Pseudomonas), C.D.-Critical Difference, C.V.-Coefficient of Variance, S.Em.-Standard Error of Mean. 
Table.2 Effect of Plant growth promoting rhizobacteria (PGPR) on total phenol, true protein, and free amino acids of Coriander (C. sativum L.) seedling

\begin{tabular}{|c|c|c|c|c|c|c|c|c|c|c|c|c|c|c|c|}
\hline \multirow{3}{*}{ Treatments } & \multicolumn{5}{|c|}{ Total phenol (mg.g $\left.{ }^{-1} \%\right)$} & \multicolumn{5}{|c|}{ True protein (\%) } & \multicolumn{5}{|c|}{ Free amino acids (\%) } \\
\hline & \multicolumn{5}{|c|}{ DAG } & \multicolumn{5}{|c|}{ DAG } & \multicolumn{5}{|c|}{ DAG } \\
\hline & 5 & 10 & 15 & 20 & $\begin{array}{c}\text { Mean } \\
\text { (T) }\end{array}$ & 5 & 10 & 15 & 20 & $\begin{array}{c}\text { Mean } \\
\text { (T) }\end{array}$ & 5 & 10 & 15 & 20 & $\begin{array}{c}\text { Mean } \\
(\mathbf{T})\end{array}$ \\
\hline $\mathbf{T}_{1}$ & 0.231 & 0.241 & 0.259 & 0.269 & 0.250 & 3.18 & 3.39 & 3.66 & 0.269 & 3.52 & 0.031 & 0.026 & 0.019 & 0.010 & 0.022 \\
\hline $\mathbf{T}_{2}$ & 0.243 & 0.251 & 0.272 & 0.282 & 0.262 & 3.61 & 3.73 & 3.87 & 0.282 & 3.82 & 0.034 & 0.029 & 0.022 & 0.014 & 0.025 \\
\hline $\mathbf{T}_{3}$ & 0.249 & 0.256 & 0.276 & 0.287 & 0.267 & 3.64 & 3.78 & 3.96 & 0.287 & 3.90 & 0.036 & 0.030 & 0.023 & 0.015 & 0.026 \\
\hline $\mathbf{T}_{4}$ & 0.241 & 0.246 & 0.265 & 0.277 & 0.257 & 3.41 & 3.56 & 3.75 & 0.277 & 3.66 & 0.033 & 0.028 & 0.021 & 0.012 & 0.024 \\
\hline $\mathbf{T}_{5}$ & 0.270 & 0.279 & 0.301 & 0.315 & 0.291 & 3.90 & 4.32 & 4.51 & 0.315 & 4.38 & 0.040 & 0.035 & 0.027 & 0.020 & 0.031 \\
\hline $\mathbf{T}_{6}$ & 0.260 & 0.267 & 0.289 & 0.297 & 0.278 & 3.71 & 3.87 & 4.11 & 0.297 & 4.01 & 0.038 & 0.032 & 0.026 & 0.017 & 0.028 \\
\hline $\mathbf{T}_{7}$ & 0.264 & 0.273 & 0.295 & 0.305 & 0.284 & 3.84 & 4.12 & 4.38 & 0.305 & 4.26 & 0.039 & 0.034 & 0.027 & 0.019 & 0.030 \\
\hline $\mathbf{T}_{8}$ & 0.276 & 0.284 & 0.311 & 0.324 & 0.299 & 4.63 & 4.85 & 5.25 & 0.324 & 5.03 & 0.031 & 0.035 & 0.028 & 0.019 & 0.031 \\
\hline Mean (S) & 0.254 & 0.262 & 0.284 & 0.295 & & 3.74 & 3.95 & 0.284 & 4.41 & & 0.036 & 0.031 & 0.024 & 0.016 & \\
\hline & $\mathbf{S}$ & $\mathbf{T}$ & $\mathbf{S} \times \mathbf{T}$ & & & $\mathbf{S}$ & $\mathbf{T}$ & $\mathbf{S} \times \mathbf{T}$ & & & $\mathbf{S}$ & $\mathbf{T}$ & $\mathbf{S} \times \mathbf{T}$ & & \\
\hline S.Em. \pm & 0.002 & 0.002 & 0.004 & & & 0.05 & 0.07 & 0.15 & & & 0.003 & 0.0003 & 0.001 & & \\
\hline C.D. at $5 \%$ & 0.004 & 0.005 & 0.012 & & & 0.15 & 0.18 & 0.42 & & & 0.0007 & 0.0009 & 0.002 & & \\
\hline C.V.\% & 3.17 & & & & & 5.00 & & & & & 5.30 & & & & \\
\hline
\end{tabular}

The values are mean of three replications

Where, $\mathrm{T}_{1^{-}}$(Control), $\mathrm{T}_{2^{-}}$(Azatobacter), $\mathrm{T}_{3^{-}}(\mathrm{PSB}), \mathrm{T}_{4^{-}}$(Pseudomonas), $\mathrm{T}_{5^{-}}($Azatobacter $+\mathrm{PSB}), \mathrm{T}_{6^{-}}$(Azatobacter + Pseudomonas $), \mathrm{T}_{7^{-}}(\mathrm{PSB}+$ Pseudomonas $),^{-}$ $\mathrm{T}_{8^{-}}($Azatobacter + PSB + Pseudomonas), C.D.-Critical Difference, C.V.-Coefficient of Variance, S.Em.-Standard Error of Mean. 
Table.3 Effect of Plant growth promoting rhizobacteria (PGPR) on Indole-3- acetic acid, Total soluble sugar, and Reducing sugar of Coriander (C. sativum L.) seedling

\begin{tabular}{|c|c|c|c|c|c|c|c|c|c|c|c|c|c|c|c|}
\hline \multirow{3}{*}{ Treatments } & \multicolumn{5}{|c|}{ Indole acetic acid $\left(\mu{\left.\mathrm{M} . \mathrm{g}^{-1}\right)}^{-1}\right.$} & \multicolumn{5}{|c|}{ Total soluble sugar (\%) } & \multicolumn{5}{|c|}{ Reducing sugar (\%) } \\
\hline & \multicolumn{5}{|c|}{ DAG } & \multicolumn{5}{|c|}{ DAG } & \multicolumn{5}{|c|}{ DAG } \\
\hline & 5 & 10 & 15 & 20 & $\begin{array}{c}\text { Mean } \\
\text { (T) }\end{array}$ & 5 & 10 & 15 & 20 & $\begin{array}{c}\text { Mean } \\
\text { (T) }\end{array}$ & 5 & 10 & 15 & 20 & $\begin{array}{c}\text { Mean } \\
\text { (T) }\end{array}$ \\
\hline $\mathbf{T}_{1}$ & 4.5 & 6.0 & 7.0 & 9.5 & 6.8 & 0.32 & 0.33 & 0.35 & 0.37 & 0.34 & 0.06 & 0.06 & 0.08 & 0.09 & 0.07 \\
\hline $\mathbf{T}_{2}$ & 8.5 & 10.5 & 11.5 & 14.1 & 11.2 & 0.35 & 0.36 & 0.37 & 0.40 & 0.37 & 0.07 & 0.07 & 0.09 & 0.12 & 0.09 \\
\hline $\mathbf{T}_{3}$ & 10.5 & 12.5 & 13.5 & 16.1 & 13.1 & 0.36 & 0.38 & 0.39 & 0.41 & 0.39 & 0.07 & 0.07 & 0.09 & 0.14 & 0.09 \\
\hline $\mathbf{T}_{4}$ & 7.0 & 8.5 & 9.0 & 12.4 & 9.2 & 0.34 & 0.36 & 0.37 & 0.40 & 0.37 & 0.06 & 0.07 & 0.09 & 0.10 & 0.08 \\
\hline $\mathbf{T}_{5}$ & 16.5 & 18.5 & 21.6 & 22.5 & 19.8 & 0.40 & 0.43 & 0.46 & 0.48 & 0.44 & 0.08 & 0.08 & 0.12 & 0.18 & 0.12 \\
\hline $\mathbf{T}_{6}$ & 13.0 & 14.5 & 15.5 & 33.1 & 19.0 & 0.38 & 0.40 & 0.41 & 0.44 & 0.41 & 0.07 & 0.08 & 0.10 & 0.16 & 0.10 \\
\hline $\mathbf{T}_{7}$ & 15.0 & 16.5 & 18.1 & 22.3 & 18.0 & 0.39 & 0.41 & 0.43 & 0.47 & 0.43 & 0.08 & 0.08 & 0.11 & 0.17 & 0.11 \\
\hline $\mathbf{T}_{8}$ & 18.0 & 20.0 & 22.5 & 36.5 & 24.2 & 0.49 & 0.44 & 0.47 & 0.60 & 0.50 & 0.08 & 0.10 & 0.13 & 0.19 & 0.13 \\
\hline \multirow[t]{2}{*}{ Mean (S) } & 11.6 & 13.4 & 14.8 & 20.8 & & 0.38 & 0.39 & 0.41 & 0.44 & & 0.07 & 0.08 & 0.10 & 0.14 & \\
\hline & $\mathbf{S}$ & $\mathbf{T}$ & $\mathbf{S} \times \mathbf{T}$ & & & $\mathbf{S}$ & $\mathbf{T}$ & $\mathbf{S} \times \mathbf{T}$ & & & $\mathbf{S}$ & $\mathbf{T}$ & $\mathbf{S} \times \mathbf{T}$ & & \\
\hline S.Em. \pm & 0.2 & 0.2 & 0.5 & & & 0.012 & 0.015 & 0.034 & & & 0.002 & 0.002 & 0.005 & & \\
\hline C.D. at $5 \%$ & 0.6 & 0.6 & 1.4 & & & 0.034 & 0.043 & 0.096 & & & 0.005 & 0.006 & 0.013 & & \\
\hline C.V.\% & 6.41 & & & & & 9.01 & & & & & 7.43 & & & & \\
\hline
\end{tabular}

The values are mean of three replications

Where, $\mathrm{T}_{1^{-}}$(Control), $\mathrm{T}_{2^{-}}$(Azatobacter), $\mathrm{T}_{3^{-}}(\mathrm{PSB}), \mathrm{T}_{4^{-}}$(Pseudomonas), $\mathrm{T}_{5^{-}}$(Azatobacter $\left.+\mathrm{PSB}\right), \mathrm{T}_{6^{-}}$(Azatobacter+ Pseudomonas $), \mathrm{T}_{7^{-}}(\mathrm{PSB}+$ Pseudomonas $)$,

$\mathrm{T}_{8^{-}}($Azatobacter + PSB + Pseudomonas), C.D.-Critical Difference, C.V.-Coefficient of Variance, S.Em.-Standard Error of Mean 
So far as mean free amino acid value for growth stages was concerned, it varied between 0.016 to $0.036 \%$. At stage $\mathrm{S}_{1}$, in a coriander seedling the highest mean free amino acid content was recorded $0.036 \%$ which gradually decreased to $0.016 \%$ at the 20 DAG i.e., $\mathrm{S}_{4}$ stage. For treatments mean free amino acid value varies between 0.016 to $0.036 \%$. At stage $S_{1}$, in a coriander seedling the highest mean free amino acid content was recorded $0.036 \%$ which gradually decreased to $0.016 \%$ at the 20 DAG i.e., $\mathrm{S}_{4}$ stage. Irrespective of stages and treatments the highest value was recorded in a combination of $\mathrm{S}_{1} \mathrm{~T}_{8}(0.040 \%)$. The data was in agreement with Ahmed et al., (2014). They reported that the effects of PGPR as seed inoculants, and white willow (Salix alba) extract as foliar and seed treatment in faba bean plants against (BYMV) increased the free proline content in comparison with control plants.

Indole acetic acid, total soluble sugar, and reducing sugar

The changes in indole acetic acid content $\left(\mu \mathrm{M} . \mathrm{g}^{-1}\right)$, Total soluble sugar $(\%)$, and reducing sugar $(\%)$ due to various treatment of plant growth promoting rhizobacteria (PGPR) during different growth stages in coriander seedlings were presented in Table.3. The data showed significant differences for growth stages, treatments, and interaction effect. The mean IAA value for growth stages, treatments, and their combinations varied from 11.6 to $20.8,6.8$ to 24.2 , and 4.5 to $36.5\left(\mu \mathrm{M} . \mathrm{g}^{-1}\right)$ respectively. Mean highest IAA for growth stages, treatments, and their combination found in stage $\mathrm{S}_{4}\left(20.8 \mu \mathrm{M} . \mathrm{g}^{-1}\right)$, Treatment $\mathrm{T}_{8}\left(24.2 \mu \mathrm{M} . \mathrm{g}^{-1}\right)$, and $\mathrm{S}_{4} \mathrm{~T}_{8}(36.5$ $\mu \mathrm{M} . \mathrm{g}-1)$ respectively. IAA is the most quantitatively important phytohormone produced by PGPR (Vessey, 2003). The mean Total soluble sugar value for growth stages, treatments, and their combinations varied from 0.380 to $0.445,0.344$ to 0.501 , and 0.318 to $0.602(\%)$ respectively. The mean highest Total soluble sugar for growth stages, treatments, and their combination found in stage $\mathrm{S}_{4}(0.445 \%)$, Treatment $\mathrm{T}_{8}$ $(0.501 \%)$, and $\mathrm{S}_{4} \mathrm{~T}_{8}(0.602 \%)$ respectively. Hafsa et al., (2014) reported that under drought stress PGPR application in maize increased the total soluble sugar.

So far as mean reducing sugar value for growth stages was concerned, it varied between 0.071 to $0.145 \%$. At stage $\mathrm{S}_{1}$, in a coriander seedling the lowest mean reducing sugar content was recorded $0.071 \%$ which gradually increased to $0.145 \%$ at the $20 \mathrm{DAG}$ i.e., $\mathrm{S}_{4}$ stage. In case of mean value of reducing sugar for the treatments irrespective of stage was concerned, the highest value recorded from the treatment having combination of 3 PGPR, i.e., $\mathrm{T}_{8}(0.126 \%)$. The highest value was recorded in a combination of $\mathrm{S}_{4} \mathrm{~T}_{8}(0.192 \%)$. Marius et al., (2013) reported that the PGPR strains improve the nutritive value of the harvested runner bean grains by enhancing the total reducing carbohydrates content up to $49.28 \%$.

In conclusion chemical fertilizer having adverse effect on soil fertility, also they are expensive to buy compared to biofertilizer. In contrast to chemical fertilizer the use of plant growth promoting rhizobacteria (PGPR) as a biofertilizer having no side effect and it increases the crop yield individually or in combination. Author studied eight treatments and four growth stages among these treatment $\mathrm{T}_{8}$ (Azatobacter $+\mathrm{PSB}+$ Pseudomonas) \& stage 4 (i.e. $20 \mathrm{DAG}$ ) are most effective that increased the biochemical parameters in coriander seedling either singly or in combination compared to control treatment.

\section{References}

Ahmed, R.S., Mohamed, S.A., Abd, M.A. and Khalid, A. 2014. Potential impacts of 
seed bacterization or salix extract in faba bean for enhancing protection against bean yellow mosaic disease. Nature and Sci., 12(10): 213-215.

Aishwath, O.P., Lal, G., Kant, K., Sharma, Y.K., Ali, S.F. and Naimuddin, 2012. Influence of biofertilizers on growth and yield of coriander under typic haplustepts. Inter. J. Seed Spic., 2: 9-14.

Alireza, P. 2015. Evaluation of flavonoids and phenols content of wheat under different lead, PGPR and Mycorrhiza levels. Bio. Fo. an Inter. J., 7(1): 309315.

Association of Official Analytical Chemists (AOAC) (2005). Official methods of analysis of AOAC International. 18th edition. Maryland, USA: AOAC International.

Barriuso, J., Solano, B.R., Lucas, J.A., Probanza, A.L., García-Villaraco, A. and Gutiérrez Mañero, F.J. 2008. PlantBacteria Interactions. Strategies and Techniques to Promote Plant Growth, J.P.S.H. Iqbal Ahmad, Willey-VCH Verlag GmbH \& Co. KGaA, Weinheim.

Bray, H.G. and Thorpe, W.V. 1954. Analysis of phenolic compounds of interest in metabolism. Metho. Biochem. Anal., 1: 27-52.

De Freitas, J.R., Banerjee, M.R. and Germida, J.J. $\quad 1997$. Phosphate-solubilizing rhizobacteria enhance the growth and yield but not phosphorus uptake of canola (Brassica napus L.). Biol. Fertil. Soils, 24: 358-364.

Ezawa, T., Smith, S.E. and Smith, F.A. 2002. $\mathrm{P}$ Metabolism and Transport in AM Fungi. Plant and soi., 244(1): 221-230.

Garcia, J.L., Probanza, A., Ramos, B. and Manero, F.J.G. 2001. Ecology, genetic diversity and screening strategies of plant growth promoting rhizobacteria. $J$. Plant Nutri. Soil Sci., 164:1-7.

Girenko, M.M. 1982. Initial material and basic trends in breeding of some uncommon species of vegetables [in Russ., Eng. abstr.]. Bull. VIR im. Vavilova, 120: 33-37.

Guenther, E. 1952. The production of essential oils: Methods of distillation, enfiorage, maceration and extraction with volatile solvents In: Guenther, E (Eds), pp 68. The essential oils. Historyorigin in plants, production analysis Kreieger publ. co. Malabar, Fiorida, USA pp. 427.

Hafsa, N. and Asghari, B. 2014. Role of plant growth promoting rhizobacteria and their exopolysaccharide in drought tolerance of maize. J. Pl. Inter., 9: 689701.

Hedge, J.E. and Hofreiter, B.T. 1962. In: Methods in Carbohydrates Chemistry, (Eds.) Whistler, R.L. and BeMiller, J.N., Academic Press, New York, 17: 420.

Kandoliya, U.K. and Vakharia, D.N. 2013. Antagonistic effect of Pseudomonas fluorescens against fusariumoxysporum f.sp. Ciceri causing wilt in chickpea. Legume Res., 36 (6): 569-575.

Khalid, A., Arshad, M., Zahir, Z.A. 2004. Screening plant growth promoting rhizobacteria for improving growth and yield of wheat. J. Appl. Microbiol., 96(3): 473-480.

Khan, M.A. and Almas, Z. 2002. Plant growth promoting rhizobacteria from rhizospheres of wheat and chick pea. Ann. Pl. Protec. Sci., 10: 265-271.

Kloepper, J.W., Schroth, M.N. and Miller, T.D. 1980. Effects of rhizosphere colonization by plant growthpromoting rhizobacteria on potato plant development and yield. Phytopatholog., 70:1078-1082.

Lee, Y.P. and Takahashi, T. 1966. An improved colorimetric determination of amino acids with the use of ninhydrin. Analy. Biochem., 14: 71.

Lowry, O.H., Rosebrough, N.J., Farr, A.L. 
and Randall, R.J. 1991. Protein measurement with folin phenol reagent. J. Biol. Chem., 193: 265-275.

Marcela, C.F., Fernanda, I.B., Marta, C.C., Letícia, A.G. and Gisele, B.S. 2014. Morphoanatomical and biochemical changes in the roots of rice plants induced by plant growth promoting microorganisms. J. of Bot., 14: 144-147.

Marius, S., Neculai, M., Vasile, S. and Marius, M. 2013. Effects of inoculation with plant growth promoting rhizobacteria on photosynthesis, antioxidant status and yield of runner bean. Romanian Biotech. Let., 18(2): 54-62.

Mazumdar, T., Goswami, C. and Talukdar, N.C. 2007. Characterization and screening of beneficial bacteria obtained on king's B agar from tea rhizosphere. Indian J. of Biotech., 6: 490-494.

Metin, T., Melek, E., Ertan, Y., Adem, G., Kenan, K., Aragöz, R., Kotan, and Atilla, D. 2014. Plant growth-promoting rhizobacteria improved growth, nutrient, and hormone content of cabbage (Brassica oleracea) seedlings. Turk. J. Agric. For., 38: 327-333.

Miller, G.L. (1972). Use of DNS reagent for determination of reducing sugar. Anal. Chem., 31: 426-428.

Mohamed, A.M., Ananthi, T., Subramanian, K.S. and Muthukrishnan, P. 2011.
Influence of mycorrhiza, nitrogen and phosphorus on growth, yield and economics of hybrid Maize. Madras Agric. J., 98 (1-3): 62-66.

Prakash, V. 1990. Leafy Spices. CRC Press Inc., Boca Raton. pp 31-32.

Purseglove, J.W., Brown, E.G., Green, C.L. and Robins, S.R.J. 1981. Spices, vol. 2 Longman New York pp. 736-788.

Simon, J.E. 1990. Essential oils and culinary herbs in: Janic K. J., Simon, J. E. (eds). Advances in new crops. Proceeding of the first National Symposium New Crops: research development, economics. Timber press, Portland, Oregon pp 472-483.

Singh, U.P., Sarma, B.K. and Singh, D.P. 2003. Effect of plant growth promoting rhizobacteria and culture filtrate of Sclerotium rolfsii on phenolic and salicylic acid contents in chickpea (Cicer arietinum). Curr. Microbiol., 46: 131-140.

Vessey, J.K. 2003. Plant growth promoting rhizobacteria as biofertilizers. $\mathrm{Pl}$. and Soi., 255: 571-586.

Zhang, F., Dashti, N., Hynes, R.K. and Smith, D.I. 1996. Plant Growth Promoting Rhizobacteria and Soybean [ Glycine $\max$ (L.) Merr.] Nodulation and Nitrogen Fixation at Suboptimal Root Zone Temperatures. Ann. Bot., 77(5): 453-460.

\section{How to cite this article:}

Warwate, S.I., U.K. Kandoliya, N.V. Bhadja and Golakiya, B.A. 2017. The Effect of Plant Growth Promoting Rhizobacteria (PGPR) on Biochemical Parameters of Coriander (Coriandrum sativum L.) Seedling. Int.J.Curr.Microbiol.App.Sci. 6(3): 1935-1944. doi: https://doi.org/10.20546/ijcmas.2017.603.220 